\title{
Physicochemical Properties of 3-Mercaptopyruvate Sulfurtransferase: A Cyanide Detoxifying Enzyme from the Hemolymph of Limicolaria flam- mae (Garden Snail)
}

\section{Adeola F. Ehigie', Raphael E. Okonji², Fiyinfoluwa D. Ojeniyi', Mary O. Jesulade ${ }^{1}$, Leonard O. Ehigie ${ }^{1^{*}}$}

${ }^{1}$ Department of Biochemistry, College of Health Sciences, Ladoke Akintola University of Technology, Ogbomoso, Nigeria

${ }^{2}$ Department of Biochemistry, Obafemi Awolowo University, Ile-Ife, Nigeria.

\begin{abstract}
*Correspondence should be addressed to Leonard O. Ehigie: lehigie@lautech.edu.ng
Received 12th May 2020; Revised 30th July 2020; Accepted 1st August 2020

(C) 2020 Ehigie et al. Licensee Pan African Journal of Life Sciences. This is an Open Access article distributed under the terms of the Creative commons Attribution License (https://creativecommons.org/licenses/BY/4.o), which permits unrestricted use, distribution, and reproduction in any medium, provided the original work is properly cited.
\end{abstract}

\begin{abstract}
Background: 3-Mercaptopyruvate sulfurtransferase (3-MST) is a multifunctional, mitochondrial and cytoplasmic sulphurtransferase that catalyses the detoxification of cyanide to a less toxic thiocyanate. Limicolaria flammea feeds majorly on green leaves, plants and other cyanide containing foods.

Methods: 3-MST from the hemolymph of Limicolaria flammae was purified by $70 \%$ ammonium sulphate precipitation and ion exchange chromatography. The purified enzyme was characterized at different levels such as optimal activity, inhibitors, substrate preference, thermal stability and analysis of kinetic parameters.

Results: 3-MST from the hemolymph of Limicolaria flammae had a yield of $0.75 \%$ with specific activity of $0.42 \mu / \mathrm{mg} / \mathrm{ml}$. The $\mathrm{K}_{\mathrm{m}}$ values for the substrates; $\mathrm{KCN}$ and 2-Mercaptoethanol were 1.09 and 2.83 $\mathrm{mM}$, while the $\mathrm{V}_{\max }$ values were $3.08 \mu \mathrm{ml} / \mathrm{mol} / \mathrm{min}$ and $6.17 \mu \mathrm{ml} / \mathrm{mol} / \mathrm{min}$ respectively. The optimum $\mathrm{pH}$ and temperature of the enzyme were 5.0 and $60^{\circ} \mathrm{C}$ respectively. The metals $\left(\mathrm{Al}^{3+}, \mathrm{Ca}^{2+}\right.$, and $\left.\mathrm{K}^{+}\right)$ demonstrated inhibitory activity in a concentration dependent manner. The substrate specificity study showed that sodium sulphite, ammonium per sulphate and ammonium sulphite showed enzymatic interference.

Conclusion: This study affirmed the presence of 3-MST activity in the hemolymph of Limicolaria flammea, an indication that the enzyme possesses functional cyanide detoxification mechanism necessary for the survival of the animal in the environment.
\end{abstract}

Keywords: 3-mercaptopyruvate sulfurtransferase, cyanide, detoxification, Limicolaria flammea 


\section{1.o INTRODUCTION}

The enzyme 3-mercaptopyruvate sulfurtransferase (MST, EC 2.8.1.2) catalyzes the chemical reactions of $3^{-}$ mercaptopyruvate. It belongs to the family of transferases, specifically the sulfurtransferases [1]. 3MST has been known to catalyse endogenous cyanide $\left(\mathrm{CN}^{-}\right)$detoxification due to ability to transfer sulfur from the sulfur donor, 3-mercaptopyruvate (3-MP), to cyanide $\left(\mathrm{CN}^{-}\right)$, to generate thiocyanate $(\mathrm{SCN})$ which is less toxic [2]. 3-MST is widely distributed in nature amongst prokaryotes and eukaryotes [3]. Interestingly, 3-MST is localized in the cytoplasm and mitochondria, however, it is not present in all cell types [4]. 3-MST is active in the detoxification of cyanide, a potent toxin of the mitochondrial respiratory chain [5].

Although 3-mercaptopyruvate sulfurtransferase (3-MST) is a protein closely-related to rhodanese with striking similarity in active site amino acid sequence there exists some biochemical and molecular variations between them $[6,7]$. The two different sulfurtransferase (Str) enzymes have been identified and localised in different species. The two sulfurtransferases in mammals have been demonstrated to have 3-mercaptopyruvate and thiosulfate-specific activities and are characterized by different $\mathrm{Km}$ values for both substrates [8]. The $3^{-}$ mercaptopyruvate sulphurtransferase enzyme was localized to the cytoplasm and the mitochondria by immunogold-labeling and immunoblotting, whereas thiosulfate-specific sulphurtransferase was detected exclusively in mitochondria and particularly in liver cells. 3-mercaptopyruvate Str might catalyses cyanide detoxification cyanide in the cytosol while both Str enzymes would function to protect cytochrome c oxidase effectively in the mitochondria [6]. To unveil the relationship between the two enzymes, some workers in Japan examined both Thiosulphate sulphurtransferase (TST) activity and mRNA expression in MST knockout mice [9]. It was revealed that there was overexpression of rhodanese in the animals lacking MST. This gives an insight to complementary roles played by sulfurtransferases in handling cyanide detoxification. These enzymes seem to function principally in metabolism of sulfur compounds [10]. Various accounts of 3-MST physiological functions including cyanide detoxification [11], trans-sulfuration, $\mathrm{H}_{2} \mathrm{~S}$ and polysulfides production, anti-oxidative stress and redox sensing [12], possibly $\mathrm{SO}_{2}$ production, and anti-anxiety behaviour have been reported by scientists [13].

Limicolaria flammea commonly called Garden snail is a small land animal found predominantly in Sub-saharan
Africa. It is a species of tropical air-breathing land snails, a terrestrial pulmonate gastropod mollusk in the family Achatinidae [14]. This species is indigenous to West Africa, Nigeria. It consumes a wide range of green plants, which are known to contain cyanogenic glycosides. It is therefore reasonable for us to assume that the animal possesses a good and efficient cyanide detoxifying mechanism. Cyanide is known to be a potent inhibitor of cytochrome oxidase of the mitochondrial electron transport chain [15]. When consumed or inhaled, cyanide activates the innate detoxifying system, resulting in the conversion of cyanide into a less harmful compound known as thiocyanate. 3-mercaptopyruvate sulfurtransferase is one of the major enzymes of cyanide detoxification [16]. This study investigates the properties of 3-mercaptopyruvate sulfurtransferase from the hemolymph of L. flammae.

\subsection{METHODOLOGY}

\subsection{Material}

The reagents below were used during the course of the research work; 0.1 M Phosphate buffer ( $\mathrm{pH}$ 7.2), 0.3 M Tris buffer ( $\mathrm{pH}$ 7.8), 0.5 M Potassium cyanide, $0.3 \mathrm{M}$ Mercaptoethanol, $\quad$ Sodiumthiosulphate, $15 \%$ Formaldehyde, Sorbo reagent (ferric nitrite and nitric acid), Ammonium sulfate, Bradford reagent. Other chemicals used were of analytical grade and were obtained from reputable chemical firms. Garden snails (Limicolaria flammae) were collected and authenticated from the school farm, Faculty of Agriculture, Obafemi Awolowo University Ile-Ife, Osun state, Nigeria.

\subsection{Enzyme Extraction and Ammonium Sulfate Precipitation}

The samples were safely taken to the laboratory and carefully washed to remove sand and dirt. The shell of the garden snail was carefully broken at the bottom and the hemolymph was collected into a clean beaker. The hemolymph was filtered over a double layer cheese cloth to remove broken shell sediments and kept in a freezer for further analysis.

The hemolymph (47 ml) was brought to $70 \%$ ammonium sulphate saturation as described by Fagbohunka et al., [17] by slow addition and stirring of $42.05 \mathrm{~g}$ solid ammonium sulphate. This was done for 60 minutes with intermittent stirring until all the salt had solubilised completely in the supernatant. The mixture was left for 12 hours at $4^{\circ} \mathrm{C}$. The solution from the ammonium sulfate precipitation was centrifuged at about 4,000 rpm for 30 $\mathrm{min}$. The pellet was washed with a small amount of $0.1 \mathrm{M}$ 
phosphate buffer ( $\mathrm{pH}$ 7.2) and was dialyzed against several changes of $0.1 \mathrm{M}$ solution of phosphate buffer $(\mathrm{pH} 7.2)$ at $4^{\circ} \mathrm{C}$ for 8 hours using a dialysis bag. The dialysate was subjected to centrifugation at $14,000 \mathrm{rpm}$ for $15 \mathrm{~min}$ and the supernatant was assayed for enzyme activity and protein content.

\subsection{The 3-MST Assay}

The 3-MST activity was measured according to the method described by Taniguichi and Kimura [18] and Okonji and Popoola [19]. The reaction mixture contained $0.25 \mathrm{ml} 0.38 \mathrm{M}$ Tris-HCl buffer, $\mathrm{pH} 7.8,0.1 \mathrm{ml}$ of $0.5 \mathrm{M}$ $\mathrm{KCN}$, $0.1 \mathrm{ml}$ of $0.3 \mathrm{M}$ mercaptoethanol and $0.1 \mathrm{ml}$ of the enzyme solution in a final volume of $0.55 \mathrm{ml}$. The mixture was incubated at $37^{\circ} \mathrm{C}$ for $1 \mathrm{~min}$ and the reaction was stopped by adding $0.25 \mathrm{ml}$ of $15 \%$ formaldehyde, followed by the addition of $0.75 \mathrm{ml}$ of Sorbo reagent. The absorbance was taken at $460 \mathrm{~nm}$. One unit of enzyme activity (U) was taken as the amount of enzyme [20]. Protein content was determined by the method of Bradford [21] and standard curve was generated using Bovine Serum Albumin (BSA). The reaction mix consists of $10 \mu \mathrm{l}$ of the enzyme solution and $1.0 \mathrm{ml}$ of Bradford reagent. The absorbance was read at $595 \mathrm{~nm}$

\subsection{Ion-Exchange Chromatography on CM- sephadex C-25}

CM-sephadex cation exchanger was used in purification of the enzyme solution obtained from preceding step according to the method of Fagbohunka et al., [17]. CMSephadex C-25 was prepared by the following steps: $10 \mathrm{~g}$ of the CM-Sephadex C-25 was dissolved in $100 \mathrm{ml}$ of the buffer or distilled water. It was allowed to swell for 48 hours (sephadex rises 4.5 fold). $100 \mathrm{ml} 0.1 \mathrm{M} \mathrm{HCl}$ acid was added for 30 minutes after which the acid was decanted and the resin was washed with distilled water several times to ensure total removal of the acid. $100 \mathrm{ml}$ 0.1 $\mathrm{M} \mathrm{NaOH}$ was added to the resin which was decanted after 30 minutes followed by thorough rinsing with distilled water to remove all traces of the base. The resin was then equilibrated with $0.1 \mathrm{M}$ phosphate buffer $(\mathrm{pH}$ 7.6) before it was packed into the column. Two millilitres $(2 \mathrm{ml})$ of sample was then layered on the column and the fractions were collected using 30 elution tubes, $2 \mathrm{ml}$ per tube. Immediately the column was layered with sample, o.1 M phosphate buffer was continuously added to the column to remove unbound protein. Stepwise elution was then done by changing the elution buffer from $0.1 \mathrm{M}$ phosphate buffer to phosphate buffer containing $0.1 \mathrm{M}$ $\mathrm{NaCl}$ salt. The elutes were then assayed for protein concentration and enzyme activity. The active elutes were pooled.

\subsection{Kinetic parameters and Substrate Specificity}

Kinetic parameters $\left(K_{m}\right.$ and $\left.V_{\max }\right)$ of the enzyme were determined by varying concentration of Mercaptoethanol between $30 \mathrm{mM}$ and $300 \mathrm{mM}$ at a fixed concentration of $0.5 \mathrm{M} \mathrm{KCN}$ and also the concentration of $\mathrm{KCN}$ between $50 \mathrm{mM}$ and $500 \mathrm{mM}$ at a fixed concentration of $0.3 \mathrm{M}$ Mercaptoethanol. Graphical Plots of the reciprocal of initial reaction velocity $(1 / \mathrm{V})$ versus reciprocal of the varied substrates $1 /[\mathrm{S}]$ at each fixed concentrations of the other substrate were made according to Lineweaver-Burk model [22]

The substrate specificity of 3-mercaptopyruvate sulfurtransferase was investigated by testing its activity towards structurally related compounds. The most commonly used substrate for 3 -MST is 2mercaptoethanol. The substrate specificity of the enzyme was determined by replacing 2-mercaptoethanol with different sulphur-containing compounds such as ammonium sulphate, ammonium per sulphate, sodium thiosulphate, in a typical 3- MST assay mixture. The calculated activity was expressed as a percentage (\%) activity of the enzyme using mercaptoethanol which was the control substrate.

\subsection{Effect of pH, Temperature and Metalic Salts on the Enzyme Activity}

The Purified enzyme was assayed using different buffers of varying $\mathrm{pH}$ which includes: $50 \mathrm{mM}$ citrate buffer $(\mathrm{pH} 4$ -5); $50 \mathrm{mM}$ phosphate buffer ( $\mathrm{pH} \mathrm{6-7);50} \mathrm{mM} \mathrm{tris} \mathrm{buffer}$ (pH 8) and 50mM borate buffer ( $\mathrm{pH} 9-10)$. The 3-MST activity was assayed as described earlier with the assay buffer being replaced by these buffers.

The enzyme was assayed at temperatures between $40^{\circ} \mathrm{C}$ to $90^{\circ} \mathrm{C}$ to investigate the effect of change in temperature on the activity of the enzyme and to determine the optimum temperature of the enzyme. The assay mixture was first incubated at the indicated temperature for 15 min before initiating reaction by the addition of an aliquot of the enzyme which had been equilibrated at the same temperature.

The inhibition effect of various metal ions on the activity of 3-MST was also studied. The salts used were: Aluminium chloride $\left(\mathrm{AlCl}_{3}\right)$, Calcium chloride $\left(\mathrm{CaCl}_{2}\right)$, and Potassium chloride $(\mathrm{KCl})$ at concentrations of $1 \mathrm{mM}$, $5 \mathrm{mM}$ and $8 \mathrm{mM}$ each.

\subsection{Inhibitory Study and Heat Stability}

The inhibitory effect of Urea and EDTA was determined at concentrations of $1.0 \mathrm{mM}, 3.0 \mathrm{mM}, 5.0 \mathrm{mM}$, and 10 $\mathrm{mM}$ each. 
Table 1. Quantification of the Purification Protocol for 3-Mercaptopyruvate Sulfurtransferase from Hemolymph of L. flammae

\begin{tabular}{llllll}
\hline Fractions & $\begin{array}{l}\text { Total pro- } \\
\text { tein (mg) }\end{array}$ & $\begin{array}{l}\text { Total Activity } \\
(\mathbf{U})^{\mathbf{b}}\end{array}$ & $\begin{array}{l}\text { Specific Activity } \\
(\mathbf{U} / \mathbf{m g} / \mathbf{m l})\end{array}$ & \% yield & $\begin{array}{l}\text { Purification } \\
\text { fold }\end{array}$ \\
\hline Crude & 164 & 584.5 & 3.56 & 100 & $\mathbf{1}$ \\
$\begin{array}{l}\text { 70\% ammonium sulphate } \\
\text { precipitation }\end{array}$ & 53.32 & 68.25 & 1.28 & 11.68 & 0.36 \\
$\begin{array}{l}\text { CM Sephadex C-25 ion } \\
\text { exchange (pooled peak) }\end{array}$ & 10.55 & 4.38 & 0.42 & 0.75 & 0.12 \\
\hline
\end{tabular}

a Protein concentration determined by Bradford assay using BSA as a standard protein

b Enzyme activity measured as described in methods section

Thermal stability of the enzyme was determined by incubating $2 \mathrm{ml}$ of the enzyme at $40^{\circ} \mathrm{C}, 50^{\circ} \mathrm{C}, 60^{\circ} \mathrm{C}$, and $70^{\circ} \mathrm{C}$ for $10,20,30,40,50$, and 60 minutes of each temperature respectively. From the incubated solution, $0.1 \mathrm{ml}$ was withdrawn at $10 \mathrm{~min}$ intervals and assayed for residual activity.

\subsection{RESULTS}

\subsection{Purification profile of 3-MST from Hemolymph of L.flammae}

The purification profile for 3-mercatopyruvate sulfurtransferase from the hemolymph of $L$. flammae produced a yield of $0.75 \%$ with a specific activity of 0.42 $\mu / \mathrm{mg} / \mathrm{ml}$. The purification protocol is summarized in Table 1. Figure 1 shows elution profile of Ion exchange chromatography on CM-Sephadex C-25

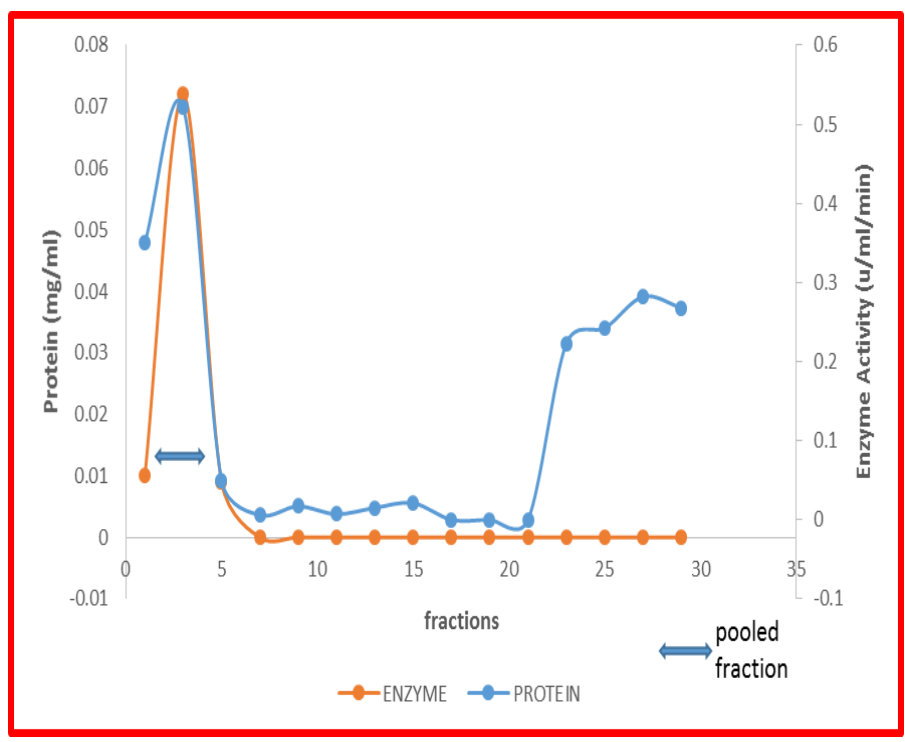

Figure 1. Elution Profile on CM-Sephadex-C-25 Ion exchange Chromatography for 3-MST from Hemolymph of $\mathrm{Li}$ micolaria flammae

\subsection{Kinetic parameter of 3-MST from Hemolymph of L.flammae}

The kinetic parameter for hemolymph of garden snail $\left(\mathrm{K}_{\mathrm{m}}\right.$ and $\mathrm{V}_{\max }$ ) were determined using the double reciprocal (Lineweaver-Burk) plot. This was achieved by varying the concentration of mercaptoethanol and potassium cyanide and then measuring the activity. Figures 2 and 3, and Table 2 shows the kinetic parameters

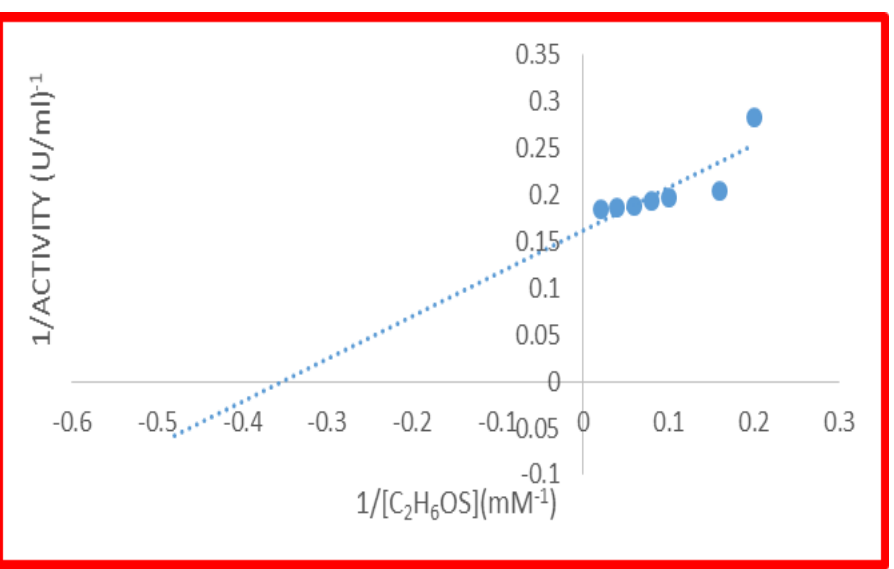

Figure 2. Lin ew eaver-Burk plot for 3-MST from Hemolymph of L. flammae at varying Concentration of Mercaptoethanol

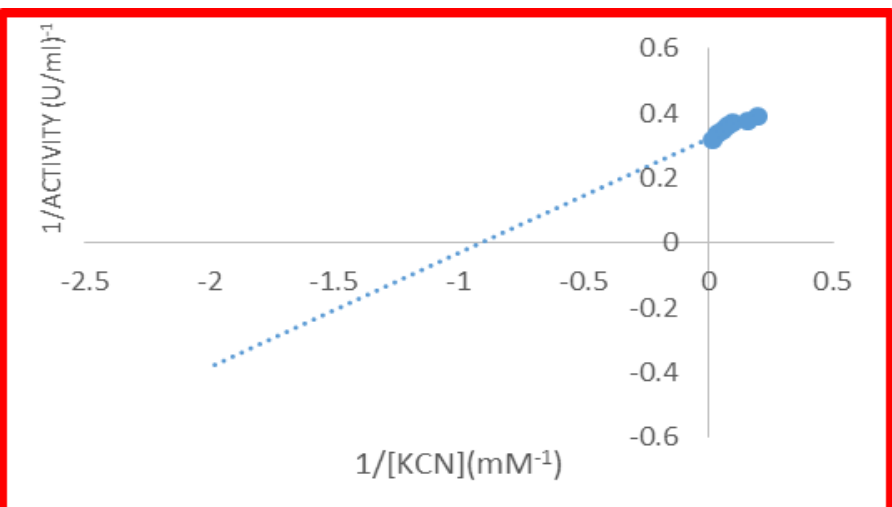

Figure 3. Lin ew eaver-Burk Plot for 3-MST from Hemolymph of L. flammae at Varying Concentration of Potassium Cyanide (KCN) 
Table 2. Kinetic Parameters of 3-MST from Hemolymph of L. flammae

\begin{tabular}{|c|c|c|}
\hline Substrates & $\begin{array}{l}V_{\max }(\mu \mathrm{mol} / \mathrm{ml} / \\
\min )\end{array}$ & $\mathrm{K}_{\mathrm{m}}(\mathrm{mM})$ \\
\hline $\mathrm{KCN}$ & 3.08 & 1.09 \\
\hline MERCAP- & 6.17 & 2.83 \\
\hline TOETHANOI & & \\
\hline
\end{tabular}

3.3 Effect of Temperature, $\mathrm{pH}$ and Metals on Activity of 3-MST from Hemolymph of L. flammae

The activity of 3-mercaptopyruvate sulfurtransferase in the hemolymph of garden snail was assayed at a temperature between $40^{\circ} \mathrm{C}$ to $90^{\circ} \mathrm{C}$. The effect of temperature on the enzyme activity shows that the enzyme has maximum activity at $60^{\circ} \mathrm{C}$ for 50 mins (Figures 4 and 5)

The activity of 3-mercapotopyruvate sulfurtransferase was determined in the assayed buffer $\mathrm{pH}$ range from 4 to 10 at $37^{\circ} \mathrm{C}$. The optimum $\mathrm{pH}$ of $3-\mathrm{MST}$ was at $\mathrm{pH}$ 5.0. This is depicted in Figure 6.The assay was done to determine the effect of metals at different concentrations of 1, 5 and $8 \mathrm{mM}$ using $\mathrm{Al}^{3+}, \mathrm{Ca}^{2+}$ and $\mathrm{K}^{+}$. The metals demonstrated a slight inhibition in a concentration dependent manner (Figure 7).

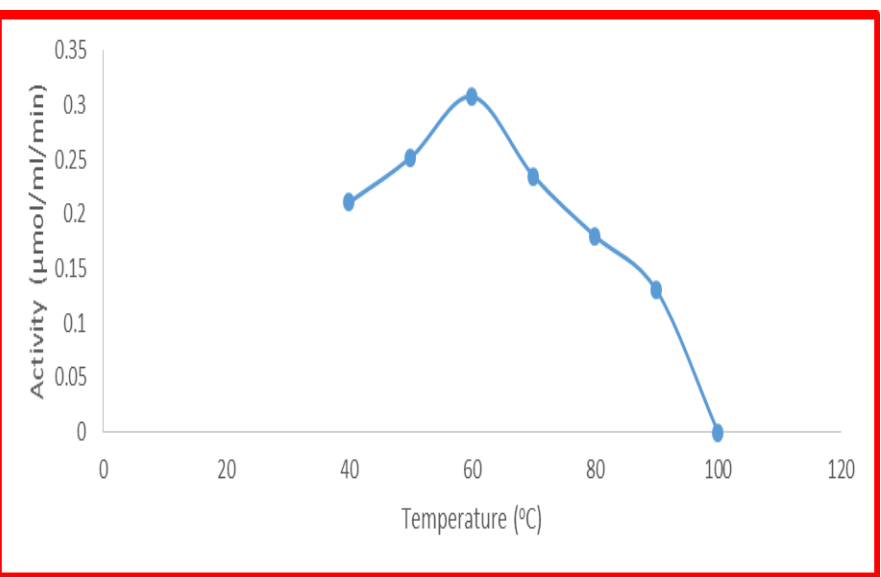

Figure 4. Temperature-activity Profile of 3-MST from Hemolymph of L. flammae.

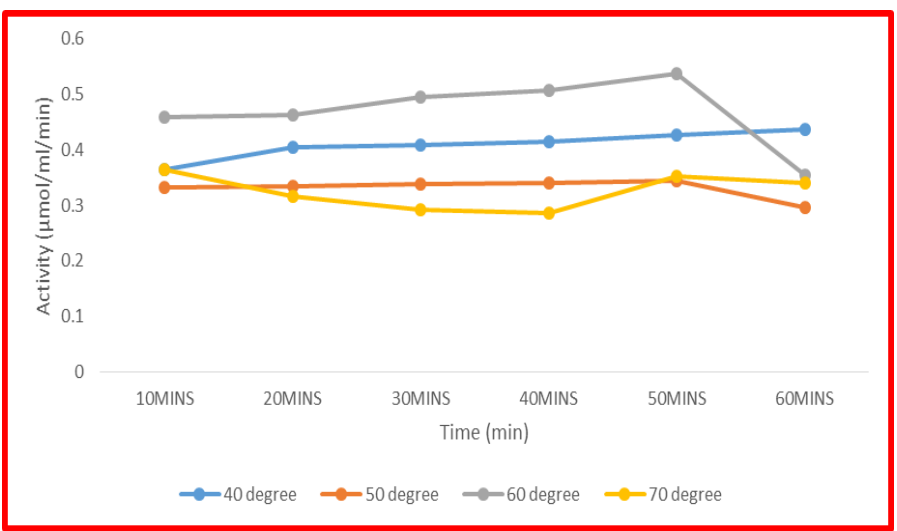

Figure 5. Heat Stability Profile of 3-MST from Hemolymph of L. flammae

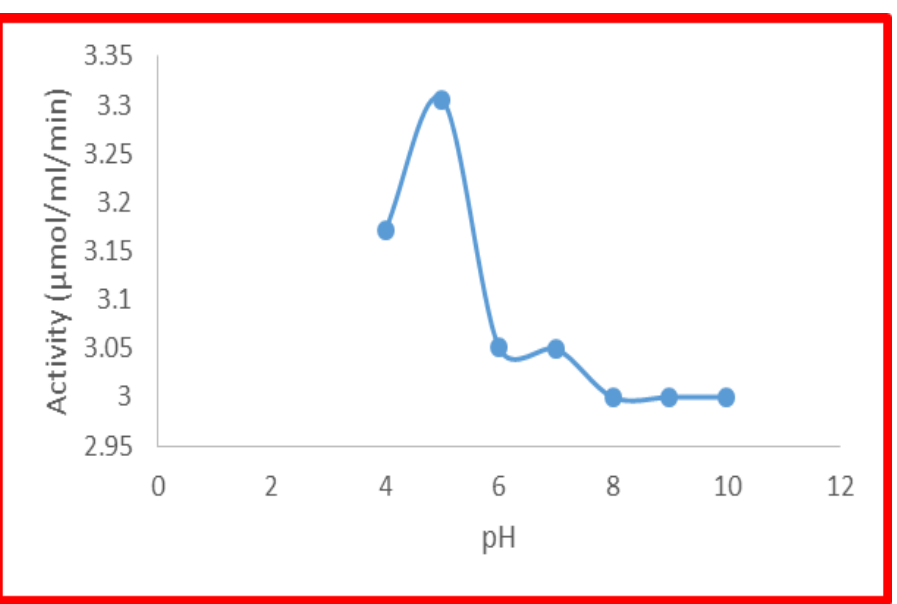

Figure 6. pH-activity profile of 3-MST from the Hemolymph of L. flammae .

\subsection{Substrate Specificity of 3-MST from Hemo- lymph of L. flammae}

Substrate specificity of 3-MST was investigated by testing its activity towards structurally related sulfur compounds in a typical 3-MST assay mixture. The sulfur compounds tested drastically decreased the enzyme activity relative to the control which is mercaptoethanol (Table 3). Figure 8 shows the degree of the inhibitory effect on the enzyme activity in the order; ammonium sulfite $>$ sodium sulfite>ammonium persulphate

Table 3. Effect of Sulfur Compounds

\begin{tabular}{ll}
\hline Substrate & \% Residual activity \\
\hline Control & 100 \\
Ammonium Sulphite & 26.93 \\
Sodium Sulphite & 28.87 \\
Ammonium per sulphate & 29.94 \\
\hline
\end{tabular}

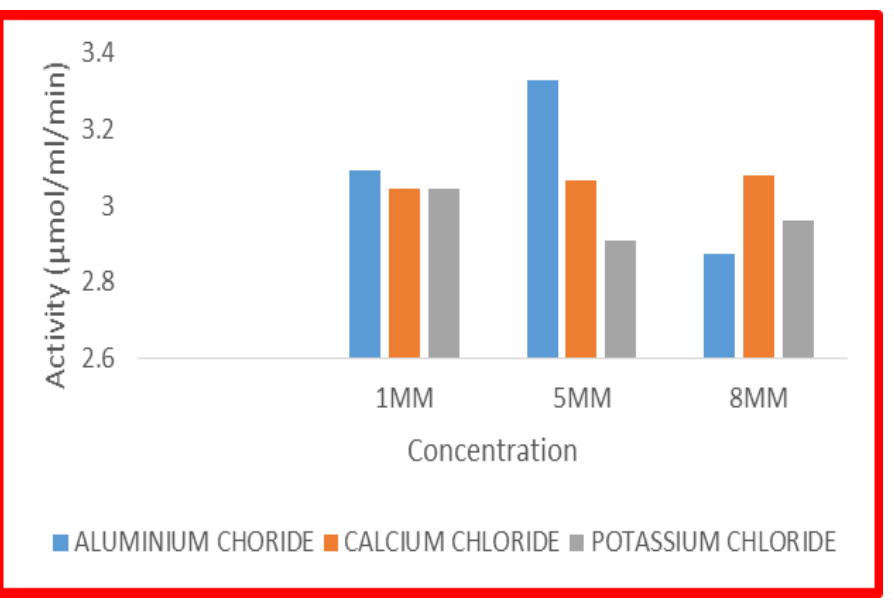

Figure 7. Effect of Metals on the Activity of 3-MST from Hemolymph of L. flammae. 


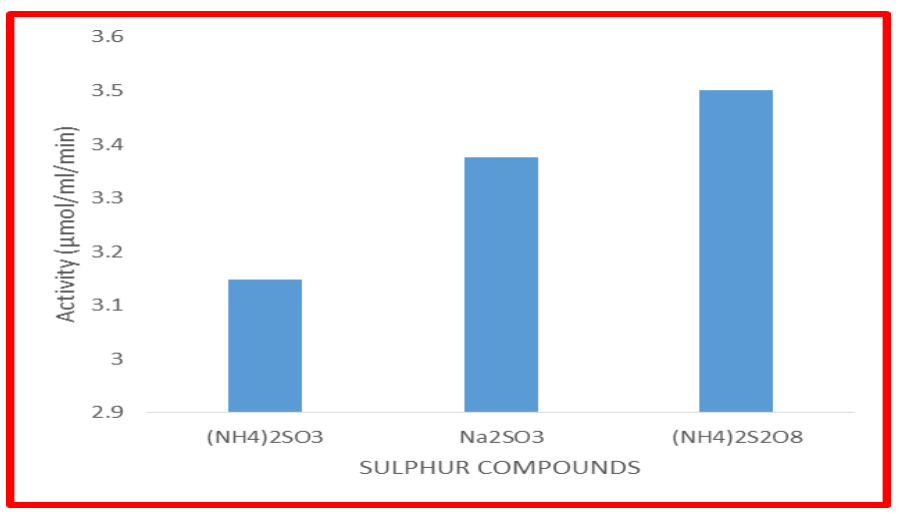

Figure 8. Effect of Sulfur Compounds on the Activity of 3-MST from Hemolymph of L. flammae

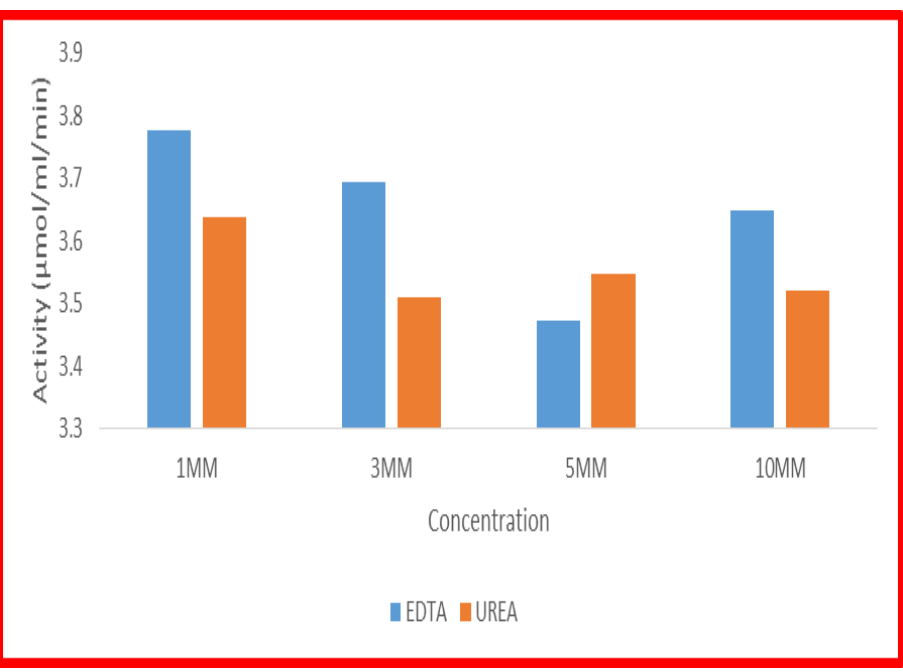

Figure 9. Effect of Urea and EDTA on the activity of 3MST from the Hemolymph of L.flammae

\subsection{Inhibitory Effects of Urea and EDTA on Activ- ity of 3-MST from Hemolymph of L. flammae}

The assay was done to dtermine the effect of Urea and EDTA at different concentrations of 1, 3, 5 and $8 \mathrm{mM}$ (Figure 9)

\section{4.o DISCUSSION}

3-mercaptopyruvate sulfurtransferase was isolated and partially purified from the hemolymph of L. flammae using ammonium sulphate precipitation and CM-Sephadex C-25 ion exchange chromatography. The specific activity of the partially purified 3-MST from the hemolymph of $L$. flammea was approximately $0.42 \mu / \mathrm{mg} / \mathrm{ml}$ with a yield of $0.75 \%$. Different specific activity values were reported for 3-MST from different sources. The specific activity of 3 -MST from onion bulb was $540 \mu / \mathrm{mg} / \mathrm{ml}$ [23]. Activity of 3-MST from liver of chicken, duck, and pigeon are 0.21 $\mu / \mathrm{mg} / \mathrm{ml}$, $0.09 \mu / \mathrm{mg} / \mathrm{ml}$ and $0.19 \mu / \mathrm{mg} / \mathrm{ml}$ respectively [24]. Fagbohunka and Agboola [17] in 2006 obtained a specific activity of $0.19 \mu / \mathrm{mg} / \mathrm{ml}$ from the gut of Tilapia mariae fish and $0.29 \mu / \mathrm{mg} / \mathrm{ml}$ from the gut of Tilapia zilli fish. They also reported that the 3-MST from gills of Tilapia mariae and Tilapia zilli have a specific activity of $0.035 \mu / \mathrm{mg} / \mathrm{ml}$ and $0.12 \mu / \mathrm{mg} / \mathrm{ml}$ respectively.

The kinetic parameters, $\mathrm{K}_{\mathrm{m}}$ and $\mathrm{V}_{\max }$ describes the affinity and the turnover number of the substrates. The $\mathrm{Km}$ and $\mathrm{V}_{\max }$ values as determined by the Lineweaver-burk plot for $\mathrm{KCN}$ and mercaptoethanol were $1.09 \mathrm{mM}, 3.08 \mu \mathrm{mol} /$ $\mathrm{ml} / \mathrm{min}$ and $2.83 \mathrm{mM}, 6.17 \mu \mathrm{mol} / \mathrm{ml} / \mathrm{min}$ respectively. The relatively high kinetic data obtained for mercaptoethanol may reveal low physiological concentration of cyanide. Moreover, this may suggest that the enzyme has other roles to play aside cyanide detoxification. Report has shown various kinetic parameters for these substrates in various organisms: bovine liver, 19.0 and 6.5 [25] bat liver, 13.36 and 19.15 [17] and cat liver, $25.4 \mathrm{mM}$ and 18.6 $\mu \mathrm{mol} / \mathrm{ml} / \mathrm{min}$ [26] for $\mathrm{KCN}$ and mercaptoethanol substrates respectively. The $\mathrm{K}_{\mathrm{m}}$ and $\mathrm{V}_{\max }$ of 3-MST in some plant tubers for sodium thiosulphate and potassium cyanide were $16.67 \mathrm{mM}$ and $20 \mathrm{mM}$ and $0.2 \mu \mathrm{mol} / \mathrm{ml} / \mathrm{min}$ and $0.24 \mu \mathrm{mol} / \mathrm{ml} / \mathrm{min}$ respectively [27]. The low values of the kinetic data as compared to the report of other workers may suggest that the organism has little exposure to cyanide compounds. It can be said that the kinetic parameters vary with the enzyme source and nature of the substrates used for the assay.

The enzymatic activity of L. flammea's (hemolymph) 3MST was optimum at $\mathrm{pH}$ 5.0. There was a rapid decline in enzyme function with increasing alkalinity. A unit increase of $\mathrm{pH}$ from 5 to 6 showed a sharp drop in the activity indicating that the enzyme was is relatively sensitive to $\mathrm{pH}$ increases. Different $\mathrm{pH}$ values have been reported for the enzyme from different species of organism. Optimum pH for L. major and L. Mexicana was 6.9-7.6 [28]. Human 3-MST has optimum pH of 8.2 [1] while 9.3-9.6 was reported for E. coli's 3-MST [23]. For suitable biotechnological application, an acidic condition must be considered. The product formation at different incubation temperature conditions showed an optimal activity at $60^{\circ} \mathrm{C}$ for L. flammea's (hemolymph) 3-MST.

Bos. taurus' and $R$. novergicus' 3-MST have optimum temperature of $30^{\circ} \mathrm{C}$ [29] while $45^{\circ} \mathrm{C}-50^{\circ} \mathrm{C}$ was reported for the enzyme in $E$. coli with loss of activity at $60^{\circ} \mathrm{C}$ [23]. The thermal stability of the enzyme indicated that the enzyme was stable between $40^{\circ} \mathrm{C}$ and $60^{\circ} \mathrm{C}$. The enzyme showed increase in activity for 50 minutes at $60^{\circ} \mathrm{C}$. These results indicate that for application of the 3 -MST from $L$. flammea's (hemolymph), the suitable temperature range could be $40-60^{\circ} \mathrm{C}$. 
The substrate specificity study showed that the enzyme has little affinity for the tested sulphur compounds (sodium sulphite, ammonium per sulphate, and ammonium sulphite). Several factors come into play in the development and utilization of a compound as a sulfur donor substrate for 3-MST. According to Porter and Baskin [30] in comparing two mercaptic acids (3- mercaptopropionic acid and 2-mercaptopropionic acid) that are structurally related to 3 -Mercaptopyruvate, it was opined that the $\alpha$ keto group of 3-Mercaptopyruvate was necessary for its utilization as a substrate, and that the position of the sulfur may also affect the binding of the tested Mercaptic acids these compounds to the enzyme. Moreover, the enzyme interference of the tested Sulphur compounds may be due to lack of hydroxyl group $(-\mathrm{OH})$ which would make them relatively non-polar compared with mercaptoethanol. This property could be largely responsible for significant inhibition. However, further in vitro enzyme kinetic studies may be needed to increase the understanding of how difference in chemical properties of the substrates affects their utilization.

Specific binding sites for some metal ions have been crystallographically documented for sulphur transferases [19]. In some of these cases, the binding of the cation has been found to promote functional effects [31]. The inhibitory effects of the metal ions tested $\left(\mathrm{Al}^{3+}, \mathrm{Ca}^{2+}\right.$ and $\left.\mathrm{K}^{+}\right)$ could be due to the interaction of these metal ions with sulphanyl groups at the active site or decrease in the availability of the substrate to the enzyme or the binding of the cations to an amino acid side chain involved in the binding or catalysis of the substrate. EDTA and Urea showed inhibitory properties against the enzyme which may be blocking the active site. The isolation, partial purification and characterization of 3 -MST was carried out in order to understand the properties and activity of the enzyme. The biochemical parameters obtained confirmed that the enzyme 3-MST is present in the hemolymph of Garden snail (L. flammea) and indicates the presence of a powerful detoxification mechanism of cyanide as it functions in the conversion of cyanide to thiocyanate, thereby improving the survival of the animal feeding on plants containing cyanide.

\section{Conflict of Interest}

The authors declare that there is no conflict of interest.

\section{Authors Contribution}

AFE conceived and designed the study, performed data analysis and manuscript writing; REO performed data collection; FDO contributed to data collec- tion and data analysis tools; MOJ contributed to data analysis; LOE contributed to study design, data analysis and writing of manuscript.

\section{References}

1. Yadav PK, Yamada K, Chiku T, Koutmos M, Banerjee R. Structure and kinetic analysis of $\mathrm{H} 2 \mathrm{~S}$ production by human mercaptopyruvate sulfurtransferase. J. Biol Chem. 2013; 288(27): 20002-20013. doi:10.1074/jbc.M113.466177

2. Hylin JW, Wood JL. Enzymatic formation of polysulfides from mercaptopyruvate. J Biol Chem. 1959; 234(8):21412144 .

3. Jarabak R, Westley J. Steady-state kinetics of $3^{-}$ mercaptopyruvate sulfurtransferase from bovine kidney. Arch Biochem Biophys. 1978; 185(2): 458-465. doi:10.1016/0003-9861(78)90189-3

4. Nagahara N, Ito T, Kitamura H, Nishino T. Tissue and subcellular distribution of mercaptopyruvate sulfurtransferase in the rat: confocal laser fluorescence and immunoelectron microscopic studies combined with biochemical analysis. Histochem Cell Biol. 1998; 110(3): 243-250. doi:10.1007/s004180050286

5. Nelson D, Cox M (2005). Lehinger principles of biochemistry. New York; w.h. freeman p. 148.ISBN o-7176-4339-6.

6. Bauer M, Dietrich C, Nowak K, Sierralta WD, Papenbrock J. Intracellular localization of Arabidopsis sulfurtransferases. Plant Physiol. 2004; 135(2): 916-926. doi:10.1104/ pp.104.040121

7. Nagahara N, Nishino T. Role of amino acid residues in the active site of rat liver mercaptopyruvate sulfurtransferase. CDNA cloning, overexpression, and site-directed mutagenesis. J Biol Chem. 1996; 271(44): 27395-27401. doi:10.1074/jbc.271.44.27395

8. Nagahara N, Tanaka M, Tanaka Y, Ito T. Novel Characterization of Antioxidant Enzyme, 3-Mercaptopyruvate Sulfurtransferase-Knockout Mice: Overexpression of the Evolutionarily-Related Enzyme Rhodanese. Antioxidants (Basel). 2019; 8(5):116. doi:10.3390/antiox8050116

9. Nagahara N, Okazaki T, Nishino T. Cytosolic mercaptopyruvate sulfurtransferase is evolutionarily related to mitochondrial rhodanese. Striking similarity in active site amino acid sequence and the increase in the mercaptopyruvate sulfurtransferase activity of rhodanese by site-directed mutagenesis. J Biol Chem. 1995; 270(27): 16230-16235. doi:10.1074/jbc.270.27.16230

10. Cipollone R, Ascenzi P, Visca P. Common themes and variations in the rhodanese superfamily. IUBMB Life. 2007; 59(2): 51-59. doi:10.1080/15216540701206859

11. Nagahara N, Ito T, Minami M. Mercaptopyruvate sulfurtransferase as a defense against cyanide toxication: molecular properties and mode of detoxification. Histol Histopathol. 1999; 14(4):1277-1286. doi:10.14670/HH-14.1277

12. Nagahara N, Yoshii T, Abe Y, Matsumura T. Thioredoxin- 
dependent enzymatic activation of mercaptopyruvate sulfurtransferase. An intersubunit disulfide bond serves as a redox switch for activation. J Biol Chem. 2007; 282(3): 1561-1569. doi:10.1074/jbc.M605931200

13. Nagahara N. Regulation of mercaptopyruvate sulfurtransferase activity via intrasubunit and intersubunit redoxsensing switches. Antioxid Redox Signal. 2013; 19(15): 1792 -1802. doi:10.1089/ars.2012.5031

14. Siong KT and Gopalasamy RC. Clements. Limicolaria flammea (Müller, 1774), another potentially invasive African land snail in tropical Asia. Tropical Conservation Science. 2011; 4(1): 97-102.

15. Olsen K, Schaal B. Microsatellite variation in cassava (Manihot esculenta, Euphorbiaceae) and its wild relatives: further evidence for a southern Amazonian origin of domestication. Am J Bot. 2001; 88(1): 131-142.

16. Aminlari M, Gilanpour H, Taghavianpour H, Veseghi T. Comparative studies on the distribution of rhodanese and beta-mercaptopyruvate sulfurtransferase in different organs of sheep (Ovis aries) and cattle (Bos taurus). Comp Biochem Physiol C. 1989; 92(2): 259-262. doi:10.1016/0742-8413(89)90050-9

17. Fagbounka, BS, Adenuga GA, Okonji RE, Agboola FK. Properties of rhodanese from hepatopancreas of giant snail, Archachatina marginata. Science Focus. 2004; 1: 7680

18. Taniguchi T, Kimura T. Role of 3-mercaptopyruvate sulfurtransferase in the formation of the iron-sulfur chromophore of adrenal ferredoxin. Biochim Biophys Acta. 1974; 364(2): 284-295. doi:10.1016/ooo5-2744(74)90014-x

19. Okonji RE, Popoola MO. The distribution of cyanide detoxifying enzymes (rhodanese and 3- mercaptopyruvate sulphurtransferase) in different speciesof the family Cichlidae (Tilapia zillii, Sarotherodon galilaeus and Oreochromis niloticus). Africal Journal of Biochemistry Research. 2010; 4(6): 163-166

20. Sorbo BH. Crystalline Rhodanese. Enzyme catalyzed reaction. Acta Chemical Scandinavia 1953b; 7: 1137-1145.

21. Bradford MM,. "A rapid and sensitive method for the quantitation of microgram quantities of protein utilizing the principle of protein-dye binding." Analytical Biochemistry.
1976; 72: 248-254.

22. Lineweaver H. and Burk D. The Determination of Enzyme Dissociation Constants. Journal of American Chemical Society. $1934 ; 56: 658-66$

23. 23. Vachek H. and Wood JL. Wood. Purification and properties of mercaptopyruvate sulfurtransferase of Escheria coli. Biochem. Biophys Acta. 1972; 258(1): 133-46.

24. Agboola FK, Bamidele SF. and Gbenga AA. Activities of Thiosulfate and 3-Mercaptopyruvate Sulfurtransferases in Poultry Birds and Fruit Bat. J. Biol. Sci. Journal of Biological Sciences. 2006; 6(5): 833-839.

25. SORBO BA colorimetric method for the determination of thiosulfate. Biochim Biophys Acta. 1957; 23:412-6.

26. Akinsiku OT, Agboola, FK, Kuku A. and Afolayan, A."Physicochemical and kinetic characteristics of rhodanese from the liver of African catfish Clarias gariepinus Burchell in Asejire lake," Fish Physiology and Biochemistry. 2010;36 (3): 573-586.

27. Ehigie OL, Okonji RE, Balogun RO and Bamitale KD. Distribution of Enzymes (Rhodanese, 3-Mercaptopyruvate Sulphurtransferase, Arginase And Thiaminase) in Some Commonly Consumed Plant Tubers in Nigeria. Special Issue - 2nd International Conference on Engineering and Technology Research.2013; 4(9):8-14.

28. Williams RA, Kelly SM, Mottram JC, Coombs GH. 3Mercaptopyruvate sulfurtransferase of Leishmania contains an unusual C-terminal extension and is involved in thioredoxin and antioxidant metabolism. J Biol Chem. 2003; 278(3):1480-1486. doi:10.1074/jbc.M209395200

29. Jarabak R. 3-Mercaptopyruvate sulfurtransferase. Methods Enzymol. 1981; 77:291-297. doi:10.1016/soo76-6879(81) 77040-X

30. Porter DW, Baskin SI. Specificity studies of 3Mercaptopyruvate sulfurtransferase. J Biochem Toxicol. 1995; 10(6):287-292. doi:10.1002/jbt.2570100602

31. Tayefi-Nasrabadi H, Keyhani E, Keyhani J. Conformational changes and activity alterations induced by nickel ion in horseradish peroxidase. Biochimie. 2006; 88(9):1183-1197. doi:10.1016/j.biochi.2006.04.001 